\title{
Stapled Financing, Value Certification, and Lending Efficiency
}

\author{
Hadiye Aslan and Praveen Kumar*
}

\begin{abstract}
We examine whether financing commitments from a target firm's financial advisor, in the form of stapled financing, provide certification of target value. Using a data set of leveraged buyouts spanning 2002-2011, and addressing endogeneity issues, we find that stapled financing has significant positive effects on sellers' shareholder wealth, especially for targets suffering from greater adverse selection. Stapled financing facilitates deal financing by allowing buyers to obtain lower-cost and longer-maturity debt, and it is positively associated with bidding intensity. Investment banks offering stapled financing appear to trade off higher expected advisory fees against loss of lending efficiency ex post.
\end{abstract}

\section{Introduction}

Uncertainty regarding the value of target firms is an important characteristic of the acquisitions process. Financial intermediaries, such as investment banks, play a major certification role by producing value-related information (Leland and Pyle (1977), Diamond (1984), and Allen (1990)). The credibility of this certification is a crucial issue, however. Although the literature emphasizes reputation as a disciplining mechanism for intermediaries, ${ }^{1}$ reputation costs may not generally be sufficient to resolve the credibility of information generation. Consequently, transaction cost theories (Coase (1937), Williamson (1975)) imply that intermediaries have incentives to produce contractual innovations that strengthen the credibility of their certifications if it improves their expected advisory fees.

*Aslan (corresponding author), haslan@gsu.edu, Robinson College of Business, Georgia State University; Kumar, pkumar@uh.edu, Bauer College of Business, University of Houston. We thank an anonymous referee for helpful comments. We also thank Audra Boone, Tom George, Andrey Golubov (European Finance Association (EFA) meeting discussant), Yaniv Grinstein, Jarrad Harford (Western Finance Association (WFA) meeting discussant), Paul Malatesta (the editor), Maureen O'Hara, Paul Povel, Raj Singh, Stuart Turnbull, and participants at seminars in various universities, the 2013 EFA meetings, and the 2013 WFA meetings for helpful comments or discussions.

${ }^{1}$ There is an extensive literature that examines the role of investment bank reputation in valuation, largely in the initial public offering (IPO) context (e.g., Logue (1973), Beatty and Ritter (1986), and Carter and Manaster (1990)). 
Stapled financing is a commitment by the target's bank to provide loans to bidders to support the purchase of the firm. Although it is a relatively recent financial innovation, it played a significant role in mergers and acquisitions (M\&A) during the leveraged buyout (LBO) boom of 2004-2007. From the viewpoint of the standard signaling framework (Spence (1973), Riley (1979)), several aspects of stapled financing are conducive to a credible certification role. It is a commitment provided publicly at the discretion of an informed intermediary, but the offering bank suffers expected lending losses because buyers only exercise the financing option only if they cannot find better financing terms elsewhere (Povel and Singh (2010)). The bank can benefit from providing stapled financing, however, if it raises commission rates and expected sale prices. Anecdotally, sellers in M\&As seem to have understood the credible certification role of stapled financing and formed expectations of higher sale prices. ${ }^{2}$

Meanwhile, there are concerns that stapled financing engenders a conflict of interest for the offering banks. These concerns are highlighted by the 2010 lawsuit filed by the shareholders of Del Monte Food Company against the company and its financial advisor Barclays Capital during the company's proposed acquisition by private equity investors. The lawsuit alleged that Barclays Capital, which had offered stapled financing, suffered a conflict of interest in favoring buyers who would exercise the financing option rather than pay the highest price (Chon and Das (2011)). More generally, this controversy reflects the tension that arises when financial intermediaries perform both a value certification and a financing function (see Puri (1996)). It is important, therefore, to examine whether stapled financing actually has significant certification effects. The academic literature on stapled financing is just beginning to emerge, however. To our knowledge, there is no available empirical examination of the certification effects of stapled financing on target value, deal financing, the bidding process, and the expected advisory fees of investment banks. ${ }^{3}$

In this article, we perform such an analysis using a unique hand-collected data set on stapled financed acquisitions of U.S. public firms during 2002-2011. We find that stapled financing is concentrated in LBOs. Indeed, the use of stapled financing in acquisitions by public firms is exceedingly rare even in large deals. This is perhaps not surprising. We expect financing commitments by banks to be most relevant for large deals with private buyers, because public acquirers have access to other funding sources. Our analysis therefore uses a comprehensive sample of LBOs of U.S. public firms during 2002-2011.

LBO targets tend to be larger, older, and more levered compared to those in public acquisitions (Bargeron, Schlingemann, Stulz, and Zutter (2008)).

\footnotetext{
${ }^{2}$ For example, in the acquisition of CDW Corporation by Providence Equity Partners, the board of CDW appreciated the certification effects of stapled financing. In the firm's preliminary proxy statement (PREM14A, Jan. 2007, https://www.sec.gov/Archives/edgar/data/899171/0001193125071 48447/dprem14a.htm), the board noted: "The providing of stapled financing would [also] underscore that a third party had confidence in the expected performance of the company. This would likely encourage bidders to put forward higher bids than they might otherwise have submitted in an initial round of bidding."

${ }^{3}$ The literature has only recently begun to study specific aspects of stapled financing. For example, Boone and Mulherin (2008) and Povel and Singh (2010) examine the effects of stapled financing on the intensity of bidding competition.
} 
Nevertheless, we find that stapled targets exhibit greater value uncertainty and higher information asymmetry (measured by empirical proxies widely used in the literature) compared to nonstapled targets. Stapled targets also tend to have lower leverage compared to the nonstapled targets, even though the former are on average larger and more profitable than the latter. This finding is consistent with the view that higher value uncertainty and asymmetric information raise the costs of debt for stapled targets (Jensen and Meckling (1976), Myers (1977)). Hence, stapled financing may be particularly effective in certifying higher debt capacity (or low intrinsic costs of debt) of targets. Estimating the pricing effects of stapled financing poses challenging identification problems, however, because financing offers by informed banks may depend on nonobservable factors correlated with the acquisition price. To address these concerns, we use an endogenous switching regressions model, which is a generalization of the classical Heckman (1979) 2 -stage procedure, to provide estimates of the pricing and financing cost improvements from stapled financing.

We find that stapled financing has significant certification effects. Controlling for target- and deal-specific factors usually considered in M\&A event studies, the benchmark cumulative abnormal returns (CARs) on stapled deals in the 4-month postevent window are about $6 \%$ higher compared to a matched sample of nonstapled deals. Moreover, these gains from stapling are positively related to the target's information asymmetry and value uncertainty. The pricing improvement associated with stapling remains economically and statistically significant even when controlling for endogeneity effects.

If stapled financing provides credible certification, its effects should be evident in the debt-financing costs of buyers even if they do not exercise the financing option. We indeed find that buyouts with stapled financing have lower loan costs and more aggressive debt structure compared to similar nonstapled deals. Ceteris paribus, stapling reduces the costs of bank loans by $15 \%$ (based on the sample mean of the originating loan spreads) and allows longer maturities of term loans compared to the hypothetical situation of no stapled financing. Meanwhile, the provision of costly financing commitments can only be incentive-compatible for banks if they generate positive expected net payoffs. Consistent with this restriction, banks offering stapled financing receive significantly higher commission rates on successful transactions compared to nonstapled deals. Thus, offering banks raise their expected advisory fees in two ways: by negotiating higher commission rates and by raising the expected sales price through the certification effect.

In light of the concerns regarding banks' conflicts of interest, we also examine the effects of stapled financing on bidding competition. We find that stapled financing is related positively and significantly to the intensity of bidding competition, based on various proxies employed in the literature (Officer, Ozbas, and Sensoy (2010), Boone and Mulherin (2011)). Ceteris paribus, the difference between the final and initial offer prices is about $5 \%$ higher for stapled deals compared to nonstapled deals. Thus, our analysis does not indicate a significant reduction in bidding competition for targets receiving stapled financing. The higher number of bidders for stapled deals is consistent with theoretical models that predict that targets subject to greater value uncertainty prefer auctions to negotiations 
(French and McCormick (1984)) and that stapled financing can intensify bidding competition (Povel and Singh (2010)).

In sum, our analysis supports the predictions of a signaling framework where informed intermediaries in M\&A certify the intrinsic value of targets by providing ex ante financing commitment. In particular, we highlight the trade-offs between information credibility and ex post lending efficiency in value certification. We also show the significant economic impact of financial contracting innovations by informed intermediaries in the market for corporate control. Our results are consistent with the view that financial contracting is motivated by minimizing the agency costs of asymmetric information (Coase (1937), Jensen and Meckling (1976)). Moreover, we extend the studies in financial intermediation that examine information production by intermediaries in IPO settings and the joint delivery of underwriting services and lending by banks (Puri (1996), Allen and Peristiani (2007)). Notably, we find that financing commitments by banks can be a substitute for institutional reputation in value certification. Our analysis also provides a novel perspective on the financing of LBOs and going-private transactions (Kaplan and Stein (1993), Guo, Hotchkiss, and Song (2011)).

\section{Theoretical Motivation and Hypotheses Development}

In this section, we theoretically motivate a certification role for stapled financing and derive empirical hypotheses that we subsequently test. We interpret stapled financing in the context of the signaling framework. We model buyers' uncertainty about sellers' value by a parameter $\theta \in \Theta \equiv\left[\theta_{\ell}, \theta_{h}\right]$ that is privately known by the sellers and their investment banks. Higher $\theta$ firms are more desirable for buyers. Thus, $\theta$ has a broad interpretation. In particular, high $\theta$ could represent high expected cash flows and/or intrinsic costs of external financing, for debt or equity, of targets. Furthermore, $F \in\{S, N S\}$ is a binary indicator denoting the decision to offer stapled financing $(S)$ or not $(N S)$.

As mentioned above, stapled financing is a commitment that generally obligates the bank to provide financing if the buyer decides to exercise the option. ${ }^{4}$ This commitment is costly, however, because buyers exercise the financing option only if they cannot find better terms elsewhere. ${ }^{5}$ Formally, if $C(\theta, F)$ denotes the expected cost to the bank conditional on the firm's true value and the stapled offer decision, then $C(\theta, S)>C(\theta, N S)$ if the option is exercised with positive probability. ${ }^{6}$ Next, let $A(\theta, P, F) \geq 0$ be the expected advisory fees to the bank from the sale process. Industry practice typically ties "success" fees in an asset sale to the final value of the transaction. Therefore, $A$ is increasing in the transaction price $P$. Moreover, $A$ is, ceteris paribus, higher with the stapled offer if the bank is able to extract higher advisory fees from the seller. In general, the

\footnotetext{
${ }^{4}$ We find that the "due diligence" or "market out" provisions, which allow lenders not to fund their commitments under certain conditions, do not typically apply to stapled offers. Typically, the only "out" available to lenders in stapled offers is relatively extreme conditions, such as bankruptcy by the seller during the deal process or very poor credit quality of the buyer.

${ }^{5}$ This argument is supported by the evidence we present in Section VI that buyers often use the stapled financing offer to obtain lower-cost and/or longer-maturity loans from other lenders.

${ }^{6}$ This condition is typically met in practice. In our sample, more than $40 \%$ of stapled offers were exercised.
} 
negotiated advisory fees also depend on $\theta$. The bank's expected utility function is thus $U(\theta, F, A)=A(\theta, P, F)-C(\theta, F)$.

If stapled financing plays a certification role, the final transaction price function $P^{*}(F)$ is such that $P^{*}(S)>P^{*}(N S)$, other things held fixed. Based on standard arguments (Riley (1979)), such an equilibrium exists if (1) $U(\theta, F, A)$ is increasing in $\theta$ and $A$; (2) $U(\cdot, S, \cdot)<U(\cdot, N S, \cdot)$ for every $(\theta, A)$, that is, the provision of the financial commitment is costly; and (3) the net gains from stapled financing to the bank in equilibrium are increasing in seller's value type. ${ }^{7}$ Under conditions (1)-(3), there exists some $\theta_{\ell}<\theta^{*} \leq \theta_{h}$ such that the bank offers stapled financing only if $\theta>\theta^{*}$. Hence, the price improvement from stapled financing is rational given that $\mathbb{E}\left[\theta \mid \theta>\theta^{*}\right]>\mathbb{E}\left[\theta \mid \theta \leq \theta^{*}\right]$.

The sufficient conditions (1)-(3) for a certification role for stapled financing are plausible. Condition (1) applies because the bank prefers higher fees and its expected payoffs are increasing in $\theta$ (the quality of the seller's assets) for a variety of reasons. First, the repayment risk from the buyer (if it exercises the financing option) is negatively related to $\theta$. Second, the expected bids are increasing with $\theta$, because potential buyers typically develop their own information, which is correlated with $\theta$. Third, the advisory fees may be positively related to $\theta$, because sellers with higher value benefit more from credible certification. In addition, condition (2) is generally satisfied, as noted above. Finally, condition (3) is satisfied if the bank obtains greater expected net benefits from offering stapled financing to high $\theta$ targets.

Notably, in equilibrium, stapled financing is associated with both a positive value impact and higher advisory fees to bankers. The certification equilibrium is incentive compatible for the target firm if the expected price improvement exceeds the higher advisory fees paid to banks for it. Firms that do not obtain stapled financing receive lower valuation because they are perceived to be of lower quality: the adverse selection discount. If this discount is sufficiently large, goodquality sellers still derive positive expected benefits from stapled financing even after paying higher bank fees. This situation is similar to other contexts where firms with positive inside value-related information bear dissipative costs to distinguish themselves, such as higher taxation costs of raising dividends (Bhattacharya (1979)) or payment of higher price premium and transaction costs in tender offers to repurchase shares (Vermaelen (1981)). Meanwhile, banks trade off the gains from higher expected advisory fees against expected lending losses on loans to buyers. Ex post efficiency requires that the stapled offer be made contingent on the buyer's characteristics, but such contingent lending terms may dilute the advisor's commitment and reduce signal credibility.

From an empirical viewpoint, the certification role of stapled financing suggests the following hypotheses. First, we expect sellers receiving stapled financing to be characterized by relatively higher value uncertainty and information asymmetry, which allows a role for costly signaling. Second, we expect significant price improvement from stapled financing, other things held fixed. In practice, price improvement occurs through intensification of bidding competition. Hence, in the third hypothesis, we expect stapled financing to be positively associated

${ }^{7}$ That is, the difference $U\left(\theta, S, A\left(P^{*}(S), S\right)\right)-U\left(\theta, N S, A\left(P^{*}(N S), N S\right)\right)$ is increasing in $\theta$. 
with the bidding competition. Fourth, we expect the financing terms of buyers in stapled deals to be superior in terms of interest rates, loan size, and loan maturity because of the certification role of stapled financing, irrespective of whether the buyer exercises the financing option. Finally, we expect advisory fees as a proportion of final sales price to be higher for stapled deals.

More generally, the impact of the financing commitment should depend also on the terms of the stapled offer (e.g., loan amount, pricing, and maturity). In particular, less-expensive financing indicates higher asset quality. Moreover, if stapled financing is provided by a syndicate of banks, the predictions are not qualitatively changed; the signaling impact is presumably driven by the most expensive loan available (or the "poorest" signal).

We now turn to the empirical tests of the hypotheses generated from the value certification view of stapled financing. We first describe the data and sample construction. All variables are defined in the Appendix.

\section{Data and Sample Characteristics}

\section{A. Sample Selection}

In our sample construction, we attempt to capture instances in which prearranged financing terms are included in offering memoranda by sellers seeking bids. Most observers agree that significant stapled financing activity started following the economic recession and financial market disruptions in 2001 (see Povel and Singh (2010) and the references cited therein). This view is confirmed by our sample (see below). We therefore define our sample period as Jan. 1, 2002 through Oct. 16, 2011. To access information for testing the hypotheses, we focus on acquisitions of public targets. We find, however, that stapled financing is concentrated in LBOs that are typically undertaken by private equity investment firms. This is perhaps not surprising, because public firms have multiple sources of financing acquisitions.

We therefore focus on the effects of stapled financing in LBOs of public U.S. firms. We start with all completed deals labeled "LBO" in the Securities Data Company (SDC) U.S. M\&A database (complemented with Standard \& Poor's Capital IQ database) during our sample period where the targets were U.S. incorporated public firms. We then employ filters used in the literature (e.g., Officer et al. (2010)). We require the acquirer to control less than $50 \%$ of the shares of the target at the announcement date and to obtain $100 \%$ of the target shares. We also require each target firm to match on the Center for Research in Security Prices (CRSP) and Compustat databases and to have a share code indicating a public firm $(10,11)$. We consider only deals with transaction values greater than $\$ 50$ million (in 2002 dollars) and nonmissing transaction values, target asset values, and price data around the announcement. We exclude spin-offs, self-tenders, recapitalizations, privatizations, repurchases, and exchange offers. We then identify stapled financed deals by scanning several sources and confirm stapled offers through preliminary (PREM14A) and definitive (DEFM14A) proxy statement filings. We use Capital IQ to obtain the names of the targets, advisors, potential bidders, bid and offer prices, transaction sizes, details of stapled financing packages, and other 
deal-related information. In addition, we obtain details on transaction debt financing from various sources (DealScan, SDC, Capital IQ, and proxy filings). ${ }^{8}$

Our initial sample has 75 stapled and 209 nonstapled deals. Applying filters reduces our final sample to 45 stapled and 141 nonstapled deals. ${ }^{9}$ Our final sample includes 7 strategic buyers, each of whom is wholly owned by private equity firms. Moreover, 19 buyers of stapled deals exercised the financing option, and 3 of these were strategic buyers. Panel A of Table 1 shows the distribution of the number and average size (in \$millions) of stapled and nonstapled LBO deals by year in our sample period. During the boom buyout years of 2004-2007, stapled deals represent more than $70 \%$ of the total deals (and as high as $85 \%$ of total deals in 2004). Following the collapse of deal activity during the financial crisis of 2008-2009, stapled financing again becomes relatively significant (compared to nonstapled deals) in 2010-2011. Moreover, the average size of the stapled deals is larger than nonstapled deals in most years of our sample.

\section{B. Sample Characteristics}

Panel B1 of Table 1 compares some basic financial characteristics of targets in stapled versus nonstapled LBOs and LBOs versus (non-LBO) public deals (selected using the same filters as the LBO sample). Following Bargeron et al. (2008), we calculate the market value of targets' equity 63 trading days before the announcement (in 2002 dollars). Both stapled and nonstapled LBO targets are significantly larger, more profitable, and more levered compared to targets in the non-LBO public deals. These characteristics are consistent with the literature (Bargeron et al. (2008)). We notice that stapled targets are not only significantly larger (Panel A) but also more profitable and less levered compared to nonstapled targets. Leverage is endogenous, however. Myers (1977) argues that leverage should be negatively related to growth opportunities, measured, for example, by higher intangible asset intensity and earnings volatility, characteristics also associated with greater value uncertainty and asymmetric information (Thomas (2002)). Consistent with this argument, the enterprise value multiples (based on revenues or earnings before interest, taxes, depreciation, and amortization (EBITDA)) are significantly lower for stapled firms. Moreover, stapled deals have a significantly greater number of bidders compared to nonstapled deals and public acquisitions, which is consistent with French and McCormick (1984), who predict that auctions will be preferred over negotiations when there is greater value uncertainty.

Building on the results in Panel B1 in Table 1, we analyze the heterogeneity of our sample with respect to information asymmetry. We use the following measures that are widely used in the literature.

\footnotetext{
${ }^{8}$ In particular, we check Tender Offer Statements for Third Parties (TO-T) that are filed with the U.S. Securities and Exchange Commission (SEC) when someone other than the issuer or stockholder, such as an external bidder, is tendering the offer. We also check Schedules 14A, S-4, and 13E-3, which are proxy filings with the SEC, whenever these are available in the Electronic Data Gathering, Analysis, and Retrieval (EDGAR) system.

${ }^{9}$ Extending the sample period through the end of 2012 adds only 2 stapled and 6 nonstapled deals (that meet our filters) to our sample. The results are not significantly affected by adding these deals. We discuss the recent decline in stapled financing in relation to the value certification hypothesis in Section X.
} 
TABLE 1

Stapled and Nonstapled LBOs

Panel A of Table 1 shows the number and average size of stapled financed and nonstapled financed leveraged buyouts (LBOs). Panel B provides summary statistics for all firm-years used in the analysis. All variables are defined in the Appendix. EBITDA stands for earnings before interest, taxes, depreciation, and amortization. ${ }^{*},{ }^{\star *}$, and ${ }^{* *}$ indicate significance at the $10 \%, 5 \%$, and $1 \%$ levels, respectively.

Panel A. Number and Average Size of Stapled and Nonstapled LBOs by Year

\begin{tabular}{lcc} 
& \multicolumn{2}{c}{ No. of Deals } \\
\cline { 2 - 3 }$\frac{\text { Year }}{2002}$ & Stapled & Nonstapled \\
\cline { 2 - 2 } 2003 & 11 & 1 \\
2004 & 12 & 1 \\
2005 & 29 & 5 \\
2006 & 24 & 8 \\
2007 & 36 & 9 \\
2008 & 35 & 15 \\
2009 & 2 & 5 \\
2010 & 3 & 1 \\
2011 & 13 & 7 \\
& 9 & 2
\end{tabular}

\begin{tabular}{lr}
\multicolumn{2}{c}{ Average Size of Deals (\$millions) } \\
\hline$\frac{\text { Stapled }}{7,050}$ & Nonstapled \\
\cline { 2 - 2 } 818 & 1,688 \\
1,305 & 1,177 \\
3,398 & 1,228 \\
2,435 & 2,149 \\
7,059 & 6,319 \\
6,813 & 4,907 \\
5,374 & 824 \\
4,031 & 441 \\
1,288 & 1,657 \\
& 1,771
\end{tabular}

Panel B. Summary Statistics for Stapled and Nonstapled LBOS

\begin{tabular}{|c|c|c|c|c|c|}
\hline & $\begin{array}{l}\text { Stapled } \\
\text { LBOs }\end{array}$ & $\begin{array}{c}\text { Nonstapled } \\
\text { LBOs }\end{array}$ & $\begin{array}{c}\text { Other } \\
\text { Public Deals }\end{array}$ & $\begin{array}{c}\text { Difference } \\
p \text {-Value }\end{array}$ & $\begin{array}{c}\text { Difference } \\
p \text {-Value }\end{array}$ \\
\hline Variables & 1 & 2 & 3 & $1-2$ & $1-3$ \\
\hline \multicolumn{6}{|c|}{ Panel B1. Firm and Deal Characteristics } \\
\hline Profitability & 0.148 & 0.061 & 0.050 & $0.00^{* * *}$ & $0.00^{\star \star \star}$ \\
\hline Leverage & 0.319 & 0.388 & 0.232 & $0.00^{\star \star \star}$ & $0.00^{\star \star \star}$ \\
\hline Target size (\$millions) & 2,746 & 2,022 & 1,569 & $0.00^{\star \star \star}$ & $0.00^{\star \star \star}$ \\
\hline Average deal value (\$millions) & 5,260 & 3,455 & 2,187 & $0.01^{\star \star *}$ & $0.01^{\star \star \star}$ \\
\hline Total deal value (\$millions) & 205,057 & 469,279 & $3,939,490$ & $0.00^{\star \star \star}$ & $0.00^{\star \star \star}$ \\
\hline Average TEV/Revenue & 2.11 & 2.93 & 2.99 & $0.04^{* *}$ & $0.00^{* *}$ \\
\hline Average TEV/EBITDA & 10.73 & 12.10 & 9.87 & $0.05^{\star *}$ & $0.08^{\star}$ \\
\hline Average number of bidders & 43.7 & 31.6 & 1.06 & $0.04^{* * *}$ & $0.00^{\star \star \star}$ \\
\hline \multicolumn{6}{|c|}{ Number of deals by transaction ranges } \\
\hline Number of deals & 45 & 141 & 1,763 & & \\
\hline Greater than $\$ 1$ billion & 36 & 76 & & & \\
\hline$\$ 500-\$ 999.9$ million & 4 & 21 & & & \\
\hline$\$ 100-\$ 499.9$ million & 4 & 33 & & & \\
\hline Less than $\$ 100$ million & 1 & 11 & & & \\
\hline \multicolumn{6}{|c|}{ Panel B2. Measures of Information Asymmetry } \\
\hline INTANGIBLES & 0.498 & 0.312 & & $0.04^{\star *}$ & \\
\hline TURNOVER & 5.319 & 7.282 & & $0.09^{*}$ & \\
\hline VOLATILITY & 0.933 & 0.620 & & $0.07^{\star}$ & \\
\hline OPACITY & 0.356 & 0.096 & & $0.00^{* \star *}$ & \\
\hline DISC_ACCRUALS & 0.050 & 0.031 & & $0.08^{\star}$ & \\
\hline
\end{tabular}

Intangibles: Barth, Kasznik, and McNichols (2001) argue that analysts' earnings forecasts are less reliable, ceteris paribus, for firms with more intangible assets. More generally, greater intangible asset intensity makes firms more difficult to evaluate and monitor by financial markets. We use the ratio of intangible-to-total assets (INTANGIBLES) for intangible asset intensity.

Earnings and Stock Return Volatility: Valuation risk and information asymmetry are higher for firms with more volatile earnings histories, which complicates inference on the true distribution of returns. We use the within-firm standard deviation of earnings (VOLATILITY). Similarly, stock volatility is likely to be positively related to valuation risk and information asymmetry. As a robustness check on our analysis, we also use firm-specific stock return volatility (see Section IX). 
Opacity Index: This composite index of adverse selection is based on measures of adverse selection developed by the market microstructure literature. We construct this index (OPACITY) for each target firm in our sample. The index uses four measures of information asymmetry and three measures of market liquidity: i) quoted bid-ask spreads; ii) effective bid-ask spreads; iii) probability of informed trading; iv) relation between daily volume and first-order return autocorrelation; v) Amihud's (2002) illiquidity ratio (see the Appendix); vi) Amivest illiquidity ratio suggested by Amihud, Mendelson, and Lauterbach (1997) (see the Appendix); and vii) the absolute value of the relation between stock returns and lagged order flows (Pastor and Stambaugh (2003)). Our measures are computed from CRSP and Trade and Quote (TAQ) data. Following Bharath, Pasquariello, and Wu (2009), we combine these measures into an index based exclusively on their first principal component.

Discretionary Accruals: A poor mapping of accruals into cash flows reduces the information content of reported earnings. If investors differ in their ability to process earnings-related information, poor earnings quality can result in differentially informed investors and exacerbate the information asymmetry in financial markets (Diamond and Verrecchia (1991)). We use discretionary accruals (DISC_ACCRUALS) suggested by Dechow and Dichev (2002).

Stock Turnover: The market microstructure literature views stock trading volume as negatively related to information asymmetry (Karpoff (1987)). We use stock trading volume divided by market capitalization (for the target firm) before the announcement of bids (TURNOVER).

The analysis is presented in Panel B2 of Table 1. Compared to nonstapled targets, stapled targets have significantly higher intangible asset intensity, earnings volatility, opacity, and discretionary accruals, but they have significantly lower stock turnover. That is, sellers receiving stapled financing exhibit greater information asymmetry based on all measures of information asymmetry. Thus, even though our sample is composed of LBOs, there is nevertheless substantial heterogeneity with respect to information asymmetry. Overall, the analysis in Table 1 is consistent with a certification role for stapled financing.

Table 2 analyzes the investment banking activity in our sample. Panel A shows the most active buyers by total transaction size. Goldman Sachs Group leads the list with $\$ 81$ billion of stapled LBO activity, followed by TPG Capital with $\$ 79$ billion, and Kohlberg Kravis Roberts \& Co. (KKR) with \$59 billion. The ranking in nonstapled deals roughly mimics the pattern in stapled deals. The largest stapled transaction in our sample is the acquisition of TXU Energy in 2007 for almost $\$ 36$ billion by an investor group led by KKR. Panel B shows the distribution of investment banks based on the number of deals, with Goldman Sachs, Credit Suisse, Merrill Lynch, and Morgan Stanley being the most active in this regard.

We examine next the certification effects of stapled financing on target value, deal financing, the bidding process, and the expected advisory fees of investment banks. 
TABLE 2

Investment Banking Activity

Table 2 shows the most active investment banks involved in stapled financed and nonstapled financed leveraged buyouts (LBOs) of U.S. incorporated public firms from Jan. 2, 2002 to Oct. 16, 2011.

Panel A. Most Active Buyers by Total Transaction Size

\begin{tabular}{|c|c|c|c|}
\hline Stapled Deals & (\$millions) & Nonstapled Deals & (\$millions) \\
\hline Goldman Sachs Group & 81.292 .34 & TPG Capital & 111.350 .31 \\
\hline TPG Capital & $79,723.34$ & Blackstone Group & $93,688.17$ \\
\hline Kohlberg Kravis Roberts \& Co. & $59,216.66$ & Carlyle Group & $74,118.09$ \\
\hline Citigroup Private Equity & $44,934.22$ & KKR & $65,967.26$ \\
\hline Bain Capital Private Equity & $24,757.62$ & Goldman Sachs Group & $63,320.08$ \\
\hline
\end{tabular}

Panel B. Distribution of Financial Advisors That Offered Stapled Financing

\begin{tabular}{lc}
\multicolumn{1}{c}{ Advisor } & $\begin{array}{c}\text { Number of } \\
\text { Stapled Offers }\end{array}$ \\
Goldman Sachs & 9 \\
Wachovia & 1 \\
UBS & 3 \\
Credit Suisse & 6 \\
JP Morgan & 4 \\
Merrill Lynch & 5 \\
Citi & 2 \\
Bank of America & 2 \\
Bear Stern & 2 \\
Lazard & 4 \\
Deutsche & 1 \\
Morgan Stanley & 5 \\
Lehman & 3 \\
Barclays Capital & 2 \\
\hline
\end{tabular}

\section{Price Improvement Effects of Stapled Financing}

\section{A. Abnormal Target Shareholder Returns}

Expectations of the sale price should be incorporated in the stock market announcement effects of the sale initiation. We calculate market-adjusted returns as the sum of the daily difference between raw returns and the CRSP value-weighted (VW) index or equal-weighted (EW) index returns over the relevant interval. We then compute raw as well as market-adjusted CARs and buy-and-hold abnormal returns (BHARs) over 3 event windows: i) postannouncement window between the announcement day $(t=0)$ and day +126 or the delisting date (whichever occurs first), ii) long window between day -42 and day +126 , and iii) short window between day -1 and day +1 , which results in the 3-day raw return (RAW3) or CARs (CAR3-VW and CAR3-EW).

\section{Univariate Analysis}

Table 3 compares the announcement returns on the initiation of sales with and without stapled financing. In the overall sample (or unmatched comparisons), the mean and median postevent abnormal returns to target shareholders with stapled deals generally exceed those for nonstapled deals in a statistically and economically significant fashion. For example, in the postannouncement window, the mean and median CAR-VW and BHAR-VW for sellers in stapled deals exceed those of nonstapled targets by more than $6 \%$, and the differences are highly statistically significant. Furthermore, the mean and median differences using the EW portfolios measures are even greater. Similarly, the mean differences between the 
TABLE 3

Target Return Measures: Univariate Comparisons

\begin{tabular}{|c|c|c|c|c|c|c|c|c|c|c|c|c|}
\hline \multirow{4}{*}{$\begin{array}{c}\text { Abnormal } \\
\text { Returns } \\
\end{array}$} & \multicolumn{6}{|c|}{ Unmatched Sample } & \multicolumn{6}{|c|}{ Matched Sample } \\
\hline & \multirow{2}{*}{\multicolumn{2}{|c|}{$\begin{array}{c}\text { Stapled } \\
1\end{array}$}} & \multirow{2}{*}{\multicolumn{2}{|c|}{$\begin{array}{c}\text { Nonstapled } \\
2 \\
\end{array}$}} & \multirow{2}{*}{\multicolumn{2}{|c|}{$\begin{array}{c}\text { Difference } \\
3 \\
\end{array}$}} & \multirow{2}{*}{\multicolumn{2}{|c|}{$\begin{array}{c}\text { Stapled } \\
4 \\
\end{array}$}} & \multirow{2}{*}{\multicolumn{2}{|c|}{$\begin{array}{c}\text { Nonstapled } \\
5 \\
\end{array}$}} & \multirow{2}{*}{\multicolumn{2}{|c|}{$\begin{array}{c}\text { Difference } \\
6 \\
\end{array}$}} \\
\hline & & & & & & & & & & & & \\
\hline & Mean & Median & Mean & Median & Mean & Median & Mean & Median & Mean & Median & Mean & Median \\
\hline \multicolumn{13}{|c|}{$[0,+126]$ Window } \\
\hline RAW & 0.231 & 0.268 & 0.144 & 0.204 & $0.061^{\star \star}$ & $0.064^{* * *}$ & 0.164 & 0.127 & 0.100 & 0.069 & $0.064^{* * *}$ & $0.058^{* *}$ \\
\hline CAR-EW & 0.188 & 0.213 & 0.112 & 0.138 & $0.076^{\star \star \star}$ & $0.075^{* * *}$ & 0.090 & 0.064 & 0.031 & 0.026 & $0.059^{* *}$ & 0.038 \\
\hline CAR-VW & 0.198 & 0.223 & 0.133 & 0.159 & $0.065^{\star \star \star}$ & $0.064^{* *}$ & 0.115 & 0.158 & 0.082 & 0.073 & 0.033 & $0.085^{* * \star}$ \\
\hline BHAR & 0.226 & 0.248 & 0.164 & 0.196 & $0.062^{\star \star}$ & $0.052^{* *}$ & 0.137 & 0.146 & 0.066 & 0.059 & $0.071^{* * *}$ & $0.087^{\text {***}}$ \\
\hline BHAR-EW & 0.163 & 0.203 & 0.092 & 0.105 & $0.071^{\star \star \star}$ & $0.098^{* * *}$ & 0.166 & 0.149 & 0.097 & 0.088 & $0.069^{* * \star}$ & $0.061^{* * *}$ \\
\hline BHAR-VW & 0.177 & 0.207 & 0.110 & 0.134 & $0.067^{\star \star \star}$ & $0.073^{\star * \star}$ & 0.173 & 0.157 & 0.088 & 0.093 & $0.085^{\star * \star}$ & $0.064^{* * *}$ \\
\hline \multicolumn{13}{|c|}{$[-42,+126]$ Window } \\
\hline RAW & 0.293 & 0.366 & 0.240 & 0.292 & $0.053^{\star \star}$ & $0.074^{* * *}$ & 0.187 & 0.158 & 0.125 & 0.082 & $0.062^{\star \star \star}$ & $0.076^{* \star \star}$ \\
\hline CAR-EW & 0.272 & 0.323 & 0.192 & 0.241 & $0.080^{\star \star \star}$ & $0.082^{* * \star}$ & 0.184 & 0.159 & 0.117 & 0.099 & $0.067^{* * \star}$ & $0.060^{* * *}$ \\
\hline CAR-VW & 0.270 & 0.335 & 0.201 & 0.252 & $0.069^{\star \star \star}$ & $0.083^{* * *}$ & 0.169 & 0.144 & 0.088 & 0.095 & $0.081^{* * \star}$ & $0.049^{*}$ \\
\hline BHAR & 0.362 & 0.346 & 0.278 & 0.291 & $0.084^{\star \star \star}$ & $0.055^{\star *}$ & 0.217 & 0.196 & 0.146 & 0.106 & $0.071^{\star \star \star}$ & $0.090^{* * *}$ \\
\hline BHAR-EW & 0.333 & 0.268 & 0.208 & 0.216 & $0.125^{\star \star \star}$ & $0.052^{* *}$ & 0.189 & 0.145 & 0.107 & 0.073 & $0.082^{\star \star \star}$ & $0.072^{* * *}$ \\
\hline BHAR-VW & 0.321 & 0.230 & 0.218 & 0.245 & $0.103^{\star \star \star}$ & -0.015 & 0.213 & 0.200 & 0.109 & 0.125 & $0.104^{* * \star}$ & $0.075^{\star \star \star}$ \\
\hline \multicolumn{13}{|c|}{$[-1,+1]$ Window } \\
\hline RAW3 & 0.213 & 0.256 & 0.148 & 0.162 & $0.065^{\star \star \star}$ & $0.094^{\star \star \star}$ & 0.159 & 0.063 & 0.074 & 0.028 & $0.085^{\star \star \star}$ & 0.035 \\
\hline CAR3-VW & 0.212 & 0.250 & 0.146 & 0.160 & $0.066^{\star \star \star}$ & $0.090^{\star \star \star}$ & 0.142 & 0.065 & 0.068 & 0.034 & $0.074^{\star \star \star}$ & 0.031 \\
\hline CAR3-EW & 0.209 & 0.251 & 0.146 & 0.161 & $0.063^{\star \star}$ & $0.090^{\star * \star}$ & 0.126 & 0.062 & 0.058 & 0.034 & $0.068^{\star \star \star}$ & 0.028 \\
\hline
\end{tabular}

stapled and nonstapled CARs in the long and short windows are both statistically and economically significant.

We also analyze announcement returns when stapled targets are matched with nonstapled targets, using propensity score matching (PSM) based on industry and size. Specifically, for each sample firm $i=1, \ldots, N$ and sample year $t$, instead of matching on a vector of characteristics $X_{i t}$, we match on the propensity score $s\left(x_{i t}\right)=\operatorname{Pr}\left(D_{i t}=1 \mid X_{i t}\right)$. Here, $D$ is a dummy variable that is equal to 1 for the treatment group (stapled LBOs) and 0 for a comparison group (nonstapled LBOs), and $X$ is a vector of characteristics for firm $i$. We first run a logit regression for the likelihood of a firm's being a treated target in $t$, using various control variables. We then use the predicted value from this regression to generate propensity scores for all treatment and comparison groups of targets. Next, both the treatment and comparison firms are randomly sorted. The closest comparison match for the first treatment firm is then identified by minimizing the absolute value of the difference between the logit of propensity scores. We replace the comparison firm once it is matched to a treatment firm. Matching with replacement minimizes the score distance between the matched firms, because each treated firm is matched to the closest comparison firm in the entire sample. We try various specifications of the characteristics vector $X_{i t}$, including industry, size, EBIDTA, sales, market-tobook ratio, and return volatility. Matching on industry and size achieves a close match; adding other variables does not materially change the matching results. For parsimony, we therefore report results for PSM on industry and size. 
The matched comparisons (in columns 4 through 6 of Table 3) show positive and significant announcement effects of stapled financing, complementing the unmatched comparison analysis. The mean CAR-VW for the stapled and nonstapled targets is depicted for the short window in Figure 1. In sum, Table 3 indicates that shareholders of sellers with stapled financed deals receive significantly greater abnormal returns, in both means and medians, compared to the shareholders of nonstapled deals.

\section{FIGURE 1}

CARs around the Event Day for Stapled and Nonstapled LBOs

Figure 1 shows the mean market-adjusted cumulative abnormal returns (CAR-VW) for the stapled (blue dotted line) and nonstapled (red dashed line) deals in the $[-1,+1]$ window. We calculate CAR-VW as the sum of daily difference between raw returns and the Center for Research in Security Prices value-weighted market index return over the $[-1,+1]$ period.

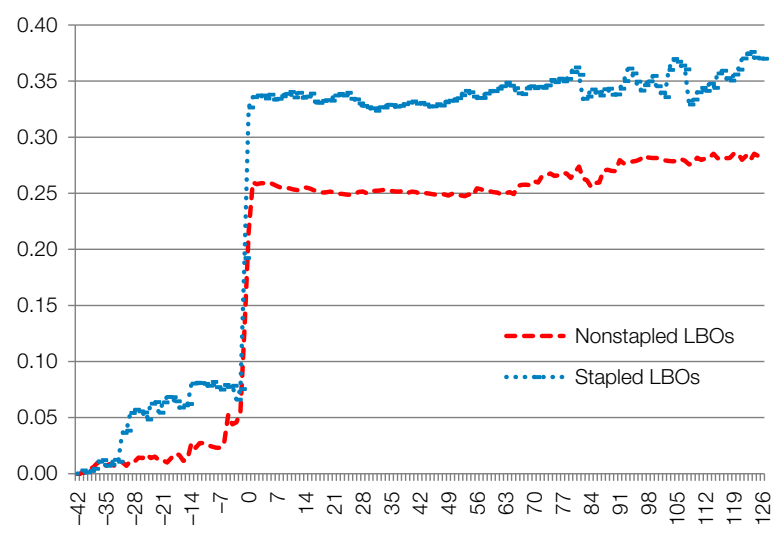

\section{Multivariate Analysis}

We analyze next the announcement effects of stapled financing using a multivariate analysis where we control for characteristics of deals, sellers, and the financial market. We run these regressions for both the postannouncement window and the long window with the CAR-VW and BHAR-VW. We also analyze the CAR-VW in the short window. These estimates are presented in Panel A of Table 4. In all cases, stapled financing has a significant positive effect on abnormal returns, other things held fixed. For example, in the postannouncement window, stapled financing, ceteris paribus, raises the CARs by $5.5 \%$, similar to the univariate analysis in Table 3 . The abnormal returns are significantly lower for firms that have experienced relatively high recent stock returns, presumably because the cost of acquisitions is higher for such sellers (Officer et al. (2010), Bargeron et al. (2008)). There are significant positive effects of tender offers, cash acquisitions, and takeover defenses on abnormal returns, consistent with the literature (Jensen and Ruback (1983)). Similarly, the number of bidders and tender bids and the presence of strategic bidders have a positive influence, complementing the acquisitions literature (Capron and Pistre (2002), Officer et al. (2010)). Note that club deals (with a consortium of bidders) are associated with significantly lower abnormal returns, even in the long event windows. In contrast, Boone and Mulherin (2011) find that the negative influence of club deals exists for short 


\section{TABLE 4}

\section{Effect of Stapled Financing on Shareholders' Gains: Multivariate Regression Results}

Panel A of Table 4 presents coefficient estimates of the impact of stapled financing on target returns. Panel B reports only coefficient estimates from regressions relating target returns to measures of asymmetric information interacted with the STAPLED indicator. BHAR-VW, CAR-VW, and CAR3-VW are described in Table 3. Firm-specific factors denote variables corresponding to value before the announcement. All control variables and information asymmetry measures are defined in the Appendix. Our sample includes all stapled leveraged buyouts (LBOs) and nonstapled LBOs. $t$-statistics are given in parentheses. ${ }^{*},{ }^{* *}$, and ${ }^{* *}$ indicate significance at the $10 \%, 5 \%$, and $1 \%$ levels, respectively.

Panel A. Baseline Results

\begin{tabular}{|c|c|c|}
\hline \multirow[b]{2}{*}{$\begin{array}{l}\text { Independent } \\
\text { Variables }\end{array}$} & \multicolumn{2}{|c|}{$\begin{array}{c}{[-42,+126]} \\
\text { BHAR-VW } \\
1\end{array}$} \\
\hline & Estimate & $t$-Stat. \\
\hline $\begin{array}{l}\text { STAPLED } \\
\text { In(RELATIVE_SIZE) } \\
\text { LEVERAGE } \\
\text { PAST_STOCK_RETURN } \\
\text { REPUTATION } \\
\text { NUMBER_OF_BIDDERS } \\
\text { TENDER } \\
\text { HOSTILE } \\
\text { CLUB_BIDDING } \\
\text { CASH } \\
\text { STRATEGIC_BIDDER } \\
\text { TAKEOVER_DEFENSE }\end{array}$ & $\begin{array}{l}0.060^{\star \star \star} \\
-0.025 \\
-0.068^{\star} \\
-0.050^{\star \star} \\
0.014^{\star \star} \\
0.010^{\star \star \star} \\
0.013^{\star \star} \\
-0.007 \\
-0.046^{\star \star \star} \\
0.010^{\star \star} \\
0.005 \\
0.006^{\star}\end{array}$ & $\begin{array}{r}(2.77) \\
(-1.29) \\
(-1.88) \\
(-2.37) \\
(2.10) \\
(2.76) \\
(2.41) \\
(-1.66) \\
(-2.56) \\
(2.10) \\
(1.54) \\
(1.80)\end{array}$ \\
\hline $\begin{array}{l}\text { Number of deals } \\
\text { Adj. } R^{2}\end{array}$ & $\begin{array}{r}186 \\
0.086\end{array}$ & \\
\hline
\end{tabular}

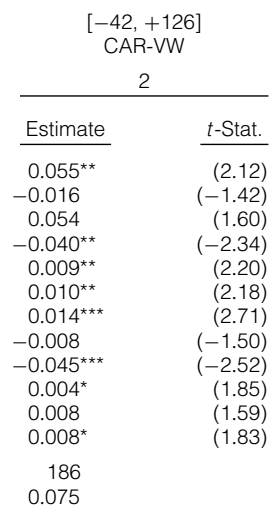

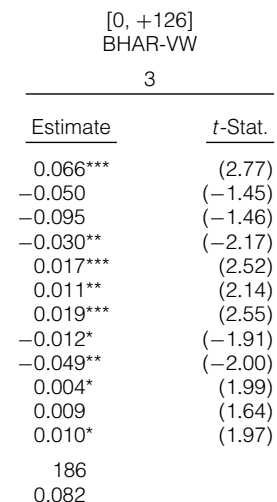

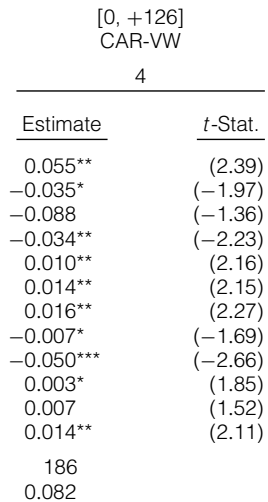

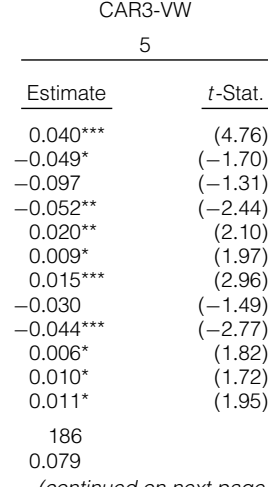


TABLE 4 (continued)

Effect of Stapled Financing on Shareholders' Gains: Multivariate Regression Results

\begin{tabular}{|c|c|c|c|c|c|}
\hline $\begin{array}{l}\text { Abnormal } \\
\text { Returns }\end{array}$ & $\begin{array}{l}\text { STAPLED } \times \\
\text { VOLATILITY } \\
\end{array}$ & $\begin{array}{c}\text { STAPLED } \times \\
\text { INTANGIBLES } \\
\end{array}$ & $\begin{array}{l}\text { STAPLED } \times \\
\text { OPACITY } \\
\end{array}$ & $\begin{array}{l}\text { STAPLED } \times \\
\text { TURNOVER } \\
\end{array}$ & $\begin{array}{c}\text { STAPLED } \times \\
\text { DISC_ACCRUALS } \\
\end{array}$ \\
\hline$[0,+126]$ BHAR-VW & $\begin{array}{l}0.055^{\star \star \star} \\
(2.52)\end{array}$ & $\begin{array}{l}0.062^{* *} \\
(2.48)\end{array}$ & $\begin{array}{l}0.027^{* *} \\
(2.19)\end{array}$ & $\begin{array}{l}-0.025^{\star \star} \\
(-2.14)\end{array}$ & $\begin{array}{l}0.034^{* *} \\
(2.29)\end{array}$ \\
\hline$[0,+126]$ CAR-VW & $\begin{array}{l}0.037^{* *} \\
(2.28)\end{array}$ & $\begin{array}{l}0.047^{* *} \\
(2.20)\end{array}$ & $\begin{array}{l}0.040^{* *} \\
(2.35)\end{array}$ & $\begin{array}{l}-0.032^{\star \star} \\
(-2.28)\end{array}$ & $\begin{array}{l}0.028^{* *} \\
(2.18)\end{array}$ \\
\hline$[-42,+126]$ BHAR-VW & $\begin{array}{l}0.041^{\star \star} \\
(2.37)\end{array}$ & $\begin{array}{l}0.061^{\star \star \star} \\
(2.56)\end{array}$ & $\begin{array}{l}0.039^{* *} \\
(2.30)\end{array}$ & $\begin{array}{l}-0.047^{\star \star \star} \\
(-2.65)\end{array}$ & $\begin{array}{l}0.026^{* *} \\
(2.15)\end{array}$ \\
\hline$[-42,+126]$ CAR-VW & $\begin{array}{l}0.034^{* *} \\
(2.28)\end{array}$ & $\begin{array}{l}0.050^{* *} \\
(2.14)\end{array}$ & $\begin{array}{l}0.042^{* *} \\
(2.48)\end{array}$ & $\begin{array}{l}-0.060^{\star \star \star} \\
(-2.81)\end{array}$ & $\begin{array}{l}0.014^{*} \\
(1.90)\end{array}$ \\
\hline CAR3-VW & $\begin{array}{l}0.022^{* *} \\
(2.06)\end{array}$ & $\begin{array}{l}0.029^{\star} \\
(1.85)\end{array}$ & $\begin{array}{l}0.025^{* *} \\
(2.06)\end{array}$ & $\begin{array}{l}-0.031^{\star \star} \\
(-2.27)\end{array}$ & $\begin{array}{l}0.038^{* *} \\
(2.26)\end{array}$ \\
\hline
\end{tabular}


announcement windows but disappears for longer event windows. Investment bank reputation has a significant positive effect on CARs, which is also consistent with the literature (Kale, Kini, and Ryan (2003)).

Panel B of Table 4 presents the estimates of the interaction effects between stapled financing and information asymmetry measures in the regression equation. For all event windows, stapled financing significantly improves the abnormal returns for firms that suffer from greater information asymmetry. The effects of other asymmetric information proxies are also statistically and economically significant in the predicted direction. These results thus support the hypothesis of a certification role for stapled financing. As we note in Section I, however, theoretically there should be certification effects from the loan terms in the stapled financing package. In particular, we expect that targets receiving relatively low debt cost (relatively short-maturity loans) will, ceteris paribus, have higher (lower) event abnormal returns. To test this hypothesis, we extract the loan terms from the stapled finance offers from the proxy statements. ${ }^{10}$ Untabulated results confirm the certification hypothesis when we interact stapled financing with below-median loan spreads and loan maturities. The statistical and economic significance of these loan terms is relatively weak compared to the effects from the presence of stapled financing, however. Thus, although financial markets extract information content from both the stapled offer and its financing terms, the economically significant information effects arise largely from the former.

\section{Controlling for Endogeneity}

The regression analysis in the previous section implicitly assumes that stapled financing is an exogenous event, but banks' decisions to provide stapled financing likely depends on nonobservable factors that are correlated with abnormal returns. Because of this omitted-variables problem, the estimated effects of stapled financing may be inconsistent. To address this issue, we pose a "what if" question: Given a stapled financing deal, what would have been the abnormal return without the financing commitment? We answer this question using an endogenous switching regression model (Maddala (1983)). A key advantage of the switching regression framework is that we obtain useful estimates of (unobserved) counterfactual outcomes. Specifically, the binary decision to offer stapled financing for deal $i, \mathrm{STAPLED}_{i}$, is modeled as the outcome of an unobserved latent variable $\mathrm{STAPLED}_{i}^{*}$ so that $\mathrm{STAPLED}_{i}=1$ if $\mathrm{STAPLED}_{i}^{*}>0$, and $\mathrm{STAPLED}_{i}=0$ otherwise. The unobserved latent variable STAPLED ST $_{i}^{*}$ is assumed to depend on a vector of variables $Z_{i}$ that are correlated with the propensity to offer stapled financing:

$$
\operatorname{STAPLED}_{i}^{*}=Z_{i}^{\prime} \gamma+u_{i} \text {. }
$$

\footnotetext{
${ }^{10}$ Of the 45 stapled deals in our sample, we could find these details in 37 deals. If multiple banks are providing offers, that is, syndicated lending, we take a conservative approach with respect to information effects and use the highest debt cost and the lowest loan maturity. The relative effects of the stapled offer versus the effects of variations in financing terms do not materially change even if we take the average of the debt costs and maturities.
} 
Here, $u_{i}$ is an error or residual term with mean zero conditional on the variables in $Z_{i}$. Next, let $y_{1 i}\left(y_{2 i}\right)$ be the target's abnormal returns if there is (is not) stapled financing. Of course, we only observe either $y_{1 i}$ or $y_{2 i}$ and never both, because $y_{i}=y_{1 i}$ if and only if (iff) $\operatorname{STAPLED}_{i}=1$, and $y_{i}=y_{2 i}$ iff $\operatorname{STAPLED}_{i}=0$. The switching regression framework then models the abnormal returns with or without stapling as 2 separate linear equations:

$$
y_{j i}=x_{i}^{\prime} \beta_{j}+\varepsilon_{j i}, \quad j=1,2,
$$

where $\varepsilon_{j i}, j=1,2$ are also mean zero error terms.

We model the endogeneity between the decision to offer stapled financing and its pricing effects by allowing the residuals in the abnormal return equation (2) to be correlated with the residuals in the stapled decision equation (1). Thus, unobserved or missing variables in the decision equation also affect the abnormal returns. The specification of the error structure and details on the estimation method are presented in the Internet Appendix (available at www.jfqa.org). This model is a generalization of the classical Heckman (1979) 2-stage procedure. Instead of 2 abnormal returns equations for the stapled and nonstapled groups (see equation (2)), under the Heckman model there is one second-stage equation that restricts the beta coefficients in equation (2) to be the same across deal types, resulting in loss of information. In our case, abnormal returns are not truncated but, rather, are generated by different types of LBOs. Hence, the 2-equation model is more appropriate for our setting.

To infer the return improvement from stapled financing, we compute the difference between the actual abnormal returns from a stapled deal for target $i$ (i.e., $y_{1 i}$ ) and the abnormal return this target would have obtained if it had received no stapled financing: the "counterfactual." This counterfactual return is easily computed by using $y_{2 i}=x_{i}^{\prime} \beta_{2}+\varepsilon_{2 i}$ from equation (2). The resultant quantity is the stapled finance price improvement:

$$
\delta_{i}=\underbrace{y_{1 i}}_{\text {actual }}-\underbrace{\mathrm{E}\left[y_{2 i} \mid \operatorname{STAPLED}_{i}^{*}>0\right]}_{\text {hypothetical }} .
$$

Intuitively, the benefits to sellers from certification should be positively related to value uncertainty and the financing needs for the deal. We therefore model the likelihood of stapled financing as a function of firm- and market-related variables pertaining to value uncertainty, deal size, and the difficulty of finding alternative financing. Based on arguments given above, we use earnings volatility to proxy for valuation risk and information asymmetry. We proxy for deal size and financing needs using size and leverage. We measure the difficulty for buyers of finding alternative financing by the number of banks giving loans in the target firm's immediate area, aggregate stock illiquidity, and credit spread. Note that, ceteris paribus, high earnings volatility should also increase the costs of alternative financing by raising the agency costs from asymmetric information. The results of the 2-stage switching regression tests (shown in Table A.1 of the Internet Appendix) confirm this intuition. Estimates of the first-stage regression (equation (1)) show that stapling is significantly more likely for larger and more levered targets and when external capital is tight. The likelihood of stapling is also positively affected by the target's informational asymmetry, which is consistent with 
the certification hypothesis and previous results. Finally, although a previous business relationship between the seller and the bank makes stapling more likely, the financial visibility from higher institutional equity ownership (Mehran and Peristiani (2009)) reduces the likelihood of stapling.

The results for the second-stage outcome (equation (2)) for the stapled and nonstapled groups indicate that sell-side advisory reputation is significantly less important in stapled deals, suggesting that stapled financing substitutes for investment bank reputation. Moreover, the negative effects of higher target leverage are significantly moderated for stapled deals, suggesting that stapled financing has certification effects when buyers' ability to finance the acquisition is uncertain. Conversely, we do not observe significant differences between stapled and nonstapled deals with respect to the characteristics of the deal or this bidding process.

Our 2-stage switching regression model allows us to address this question: What would have been the abnormal returns if banks had not offered the financing commitment? Panel A of Table 5 presents the results from this analysis. On average, stapled deals would have shown significantly lower abnormal returns in the alternative scenario of no financing commitment from banks. For instance, the improvement in the CAR-VW from stapled financing in the long window is $4.1 \%$. Conversely, during the same event window, nonstapled deals on average would have received $4.6 \%$ higher CARs if they had received the commitment. These differences are both statistically and economically significant. We observe

\section{TABLE 5}

Pricing Improvement from Stapled LBO Financing

Panel A of Table 5 presents actual and hypothetical mean value-weighted cumulative abnormal returns (CARs) for stapled and nonstapled leveraged buyouts (LBOs). Panel B replicates Panel A for high- and low-information-asymmetry (IA) groups. We rank target firms based on their VOLATILITY measures 1 quarter before the announcement date and label them as "High" ("Low") if their volatility measures are above (below) the sample median. CAR-VW and CAR3-VW are described in Table 3. Our sample includes all stapled LBOs and nonstapled LBOs. All variables are measured in percentages. *, **, and ${ }^{* * *}$ indicate significance at the $10 \%, 5 \%$, and $1 \%$ levels, respectively.

Panel A. Actual and Hypothetical CARs for Stapled and Nonstapled LBOs

\begin{tabular}{|c|c|c|c|}
\hline $\begin{array}{l}\text { Abnormal } \\
\text { Returns }\end{array}$ & Actual & Hypothetical & $\begin{array}{c}\text { Difference } \\
\text { (Actual - Hypothetical) }\end{array}$ \\
\hline $\begin{array}{l}\text { Panel A1. Comparisons } \\
{[-42,+126] \text { CAR-VW }} \\
{[0+126] \text { CAR-VW }} \\
\text { CAR3-VW }\end{array}$ & $\begin{array}{l}\text { BOs } \\
0.293 \\
0.231 \\
0.213\end{array}$ & $\begin{array}{l}0.252 \\
0.205 \\
0.189\end{array}$ & $\begin{array}{l}0.041^{\star \star} \\
0.026^{\star} \\
0.024^{\star}\end{array}$ \\
\hline $\begin{array}{l}\text { Panel A2. Comparisons } \\
{[-42,+126] \text { CAR-VW }} \\
{[0+126] \text { CAR-VW }} \\
\text { CAR3-VW }\end{array}$ & $\begin{array}{c}d \text { LBOs } \\
0.144 \\
0.240 \\
0.148\end{array}$ & $\begin{array}{l}0.190 \\
0.274 \\
0.172\end{array}$ & $\begin{array}{l}-0.046^{\star \star \star} \\
-0.034^{\star \star} \\
-0.024^{\star}\end{array}$ \\
\hline
\end{tabular}

Panel B. Actual and Hypothetical CARs for Stapled and Nonstapled LBOs Conditional on IA

\begin{tabular}{|c|c|c|c|c|c|c|}
\hline \multirow{2}{*}{$\begin{array}{c}\text { Abnormal } \\
\text { Returns }\end{array}$} & \multicolumn{2}{|c|}{ Actual } & \multicolumn{2}{|c|}{ Hypothetical } & \multicolumn{2}{|c|}{$\begin{array}{c}\text { Difference } \\
\text { (Actual - Hypothetical) } \\
\end{array}$} \\
\hline & High IA & Low IA & High IA & Low IA & High IA & Low IA \\
\hline \multicolumn{7}{|c|}{ Panel B1. Comparisons for Stapled LBOs } \\
\hline$[-42,+126]$ CAR-VW & 0.302 & 0.208 & 0.265 & 0.180 & $0.037^{\star *}$ & $0.018^{*}$ \\
\hline$[0+126]$ CAR-VW & 0.242 & 0.186 & 0.207 & 0.169 & $0.035^{\star \star}$ & $0.017^{\star}$ \\
\hline CAR3-VW & 0.222 & 0.165 & 0.202 & 0.152 & $0.020^{*}$ & 0.013 \\
\hline \multicolumn{7}{|c|}{ Panel B2. Comparisons for Nonstapled LBOs } \\
\hline$[-42,+126]$ CAR-VW & 0.258 & 0.120 & 0.213 & 0.134 & $-0.045^{\star \star \star}$ & -0.014 \\
\hline$[0+126]$ CAR-VW & 0.282 & 0.229 & 0.304 & 0.247 & $-0.022^{*}$ & $-0.018^{\star}$ \\
\hline CAR3-VW & 0.153 & 0.124 & 0.166 & 0.132 & -0.013 & -0.008 \\
\hline
\end{tabular}


similar patterns in the postannouncement and short windows. In Panel B, we analyze the pricing improvement from stapled financing based on the extent of information asymmetry (IA), using earnings volatility as the IA proxy. We find that price improvement from stapled financing is significantly greater for high-IA firms. In contrast, for the nonstapled deals, the hypothetical price improvement in the postevent window from stapled financing is significant, and roughly of the same magnitude, for both high-IA and low-IA firms.

Overall, the analysis in this section is consistent with the hypothesis that stapled financing acts as a certification device and moderates the negative effects of higher levels of asymmetric information about abnormal returns. The certification hypothesis also implies, however, that the effects of stapling will also be evident in the debt financing costs of acquisitions even if the buyer does not use the financing option (see Section II). We now turn to this analysis.

\section{Stapled Financing and Debt Financing Costs}

In an LBO, the target company's existing debt is usually refinanced and replaced with new debt to finance the transaction. Multiple tranches of debt, such as revolvers, term loans, subordinated notes, junk bonds, and mezzanine debt, are commonly used to finance LBOs. Based on the theoretical predictions in Section II, we expect that, compared to nonstapled deals, stapled buyouts should, ceteris paribus, obtain lower loan spreads and larger revolvers and have a greater proportion of financing through longer-term debt. We measure loan prices as the "drawn all-in-spread" above the benchmark at the time of loan origination, which is the standard loan pricing variable used in the bank financing literature.

Table 6 presents a univariate analysis of the effects of stapled financing on the capital structure of successful deals and their loan terms. Stapled deals have significantly lower equity-to-capital ratios and senior secured debt but have greater access to revolver loans and employ more junior debt compared to nonstapled deals. Thus, stapled financing allows greater use of debt, including higher default risk debt, in buyout financing.

Next, we examine the effects of stapling based on loan types and types of lenders. Term loan tranches are installment loans that are canceled at the repayment of the full amount, whereas revolvers allow borrowers to withdraw funds (up to a committed amount) at their discretion and then repay and replenish the loan multiple times (see Angbazo, Mei, and Saunders (1998)). Term loan tranches are further distinguished by types of lenders. Banks usually hold term A loans, whereas institutional investors prefer term B loans, which typically have longer maturities than term A loans. Table 6 shows that the loan costs for stapled deals are significantly lower than for nonstapled deals for both revolvers and terms loans. For example, the loan spreads for revolvers in stapled deals are about $18 \%$ lower compared to nonstapled deals, and the cost differential for term B loans is of comparable magnitude. The loans in the stapled deals also have significantly longer maturity; for instance, term B loans in stapled deals have, on average, 10month longer maturities compared to similar loans in nonstapled deals.

Table 7 displays a multivariate analysis of the effects of stapled financing on loan prices and maturities. We control for all significant determinants of loan 
TABLE 6

\section{Univariate Analysis of the Effect of Stapled Financing on Lending Terms}

Table 6 presents summary statistics for buyout capital structure variables for a sample of stapled and nonstapled U.S. deals. The primary sources of loan information is LPC's DealScan, Standard \& Poor's Capital IQ, and Securities Data Company. We also manually check proxy filings, including Tender Offer Statements for Third Parties and Schedules 14A, S-4, and 13E-3, for information on deal financing for all sample deals when these filings are available in the Electronic Data Gathering, Analysis, and Retrieval (EDGAR) system. For each tranche, we retrieve information on tranche type, currency, base rate, pricing, maturity, seniority, and security. Our sample includes all stapled leveraged buyouts (LBOs) and nonstapled LBOs. EBITDA stands for earnings before interest, taxes, depreciation, and amortization, and bps stands for basis points. Column 3 provides $p$-values for difference in means ( $p$-values for Wilcoxon rank sum test). ${ }^{*},{ }^{* *}$, and ${ }^{* * *}$ indicate significance at the $10 \%, 5 \%$, and $1 \%$ levels, respectively.

\begin{tabular}{|c|c|c|c|}
\hline & $\begin{array}{l}\text { Stapled } \\
\text { LBOs }\end{array}$ & $\begin{array}{l}\text { Nonstapled } \\
\text { LBOs }\end{array}$ & $\begin{array}{l}\text { Difference } \\
(p \text {-Value })\end{array}$ \\
\hline Variables & 1 & 2 & 3 \\
\hline \multicolumn{4}{|l|}{ Panel A. Capital Structure } \\
\hline $\begin{array}{l}\text { Equity/Capital } \\
\text { Debt (short and long term)/EBITDA }\end{array}$ & $\begin{array}{l}37.82 \\
5.906\end{array}$ & $\begin{array}{l}43.01 \\
4.076\end{array}$ & $\begin{array}{l}0.03^{\star \star} \\
0.09^{\star}\end{array}$ \\
\hline $\begin{array}{l}\text { Debt Ratios Relative to } \angle B O \text { Debt } \\
\text { Revolvers } \\
\text { Term loans } \\
\text { Senior bonds and notes } \\
\quad \text { Senior secured bonds } \\
\text { Senior unsecured bonds } \\
\text { Senior subordinated debt } \\
\text { Junior subordinated bonds and notes } \\
\text { Junior subordinated debt } \\
\text { Second-lien loans } \\
\text { Second-lien bonds }\end{array}$ & $\begin{array}{c}7.054 \\
25.98 \\
15.80 \\
5.489 \\
10.32 \\
3.534 \\
26.56 \\
2.461 \\
0.000 \\
1.684\end{array}$ & $\begin{array}{c}3.540 \\
22.33 \\
22.82 \\
12.00 \\
9.960 \\
2.406 \\
23.63 \\
0.674 \\
0.024 \\
0.771\end{array}$ & $\begin{array}{l}0.02^{\star \star} \\
0.08^{\star} \\
0.04^{\star \star} \\
0.03^{\star \star} \\
0.37 \\
0.19 \\
0.11 \\
0.06^{\star} \\
0.54 \\
0.26\end{array}$ \\
\hline \multicolumn{4}{|l|}{ Panel B. Spread (bps) } \\
\hline $\begin{array}{l}\text { First-lien revolvers } \\
\text { First-lien term A } \\
\text { First-lien term B } \\
\text { Bridge loans }\end{array}$ & $\begin{array}{l}238.01 \\
312.20 \\
277.90 \\
457.18\end{array}$ & $\begin{array}{l}291.94 \\
359.10 \\
339.42 \\
456.13\end{array}$ & $\begin{array}{l}0.00^{\star \star \star} \\
0.08^{\star} \\
0.00^{\star \star \star} \\
0.18\end{array}$ \\
\hline \multicolumn{4}{|l|}{ Panel C. Maturity (months) } \\
\hline $\begin{array}{l}\text { First-lien revolvers } \\
\text { First-lien term A } \\
\text { First-lien term B } \\
\text { Bridge loans }\end{array}$ & $\begin{array}{l}68.71 \\
75.29 \\
86.09 \\
10.75 \\
\end{array}$ & $\begin{array}{l}64.24 \\
70.77 \\
76.12 \\
15.91 \\
\end{array}$ & $\begin{array}{l}0.09^{\star} \\
0.09^{\star} \\
0.00^{\star \star \star} \\
0.04^{\star \star} \\
\end{array}$ \\
\hline
\end{tabular}

\section{TABLE 7}

\section{Multivariate Analysis of the Effect of Stapled Financing on Lending Terms}

Table 7 reports the determinants of leveraged buyout (LBO) loan spreads and maturity using ordinary least squares regressions at the buyout level. Bank loan involves term A loans and revolving lines of credit. All control variables are defined in the Appendix. Our sample includes all stapled LBOs and nonstapled LBOs. $t$-statistics are given in parentheses. ${ }^{*},{ }^{* *}$, and ${ }^{* * *}$ indicate significance at the $10 \%, 5 \%$, and $1 \%$ levels, respectively.

\begin{tabular}{|c|c|c|c|c|c|c|c|c|}
\hline \multirow[b]{2}{*}{$\begin{array}{l}\text { Independent } \\
\text { Variables }\end{array}$} & \multicolumn{2}{|c|}{$\begin{array}{c}\text { Bank } \\
\text { LOAN_SPREAD } \\
1\end{array}$} & \multicolumn{2}{|c|}{$\begin{array}{c}\text { Term B } \\
\text { LOAN_SPREAD } \\
2\end{array}$} & \multicolumn{2}{|c|}{$\begin{array}{c}\text { Senior } \\
\text { LOAN_SPREAD } \\
3\end{array}$} & \multicolumn{2}{|c|}{$\begin{array}{c}\text { MATURITY } \\
4\end{array}$} \\
\hline & Estimate & t-Stat. & Estimate & $t$-Stat. & Estimate & $t$-Stat. & Estimate & $t$-Stat. \\
\hline STAPLED & $-43.62^{\star \star \star}$ & $(-2.99)$ & $-35.18^{\star \star}$ & $(-2.19)$ & $-19.23^{\star \star \star}$ & $(-2.80)$ & $6.114^{* *}$ & (2.37) \\
\hline In(TARGET_SIZE) & $-34.16^{\star \star \star}$ & $(-2.90)$ & $-12.20^{\star \star \star}$ & $(-2.58)$ & $-24.60^{\star *}$ & $(-2.49)$ & $8.054^{* * *}$ & (2.92) \\
\hline LEVERAGE & $14.29^{\star \star \star}$ & (3.29) & $15.21^{\star \star}$ & $(2.85)$ & $24.50^{\star \star \star}$ & $(2.97)$ & $-3.216^{\star}$ & $(-1.74)$ \\
\hline PAST_STOCK_RETURN & $-28.60^{\star \star \star}$ & $(-3.45)$ & $-31.28^{\star \star \star}$ & $(-2.53)$ & $-8.292^{\star \star}$ & $(-2.11)$ & 0.958 & (1.04) \\
\hline INTANGIBLES & $15.27^{\star \star}$ & $(1.80)$ & $16.22^{\star \star \star}$ & $(2.70)$ & $29.66^{\star \star \star}$ & $(5.92)$ & $9.610^{* *}$ & $(2.40)$ \\
\hline VOLATILITY & 4.635 & (1.64) & $3.010^{*}$ & $(1.68)$ & $-33.12^{*}$ & $(-1.98)$ & $-2.495^{\star}$ & $(-1.90)$ \\
\hline LENDING_RELATIONSHIPS & 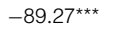 & $(-2.32)$ & $-46.33^{\star \star \star}$ & $(-2.77)$ & $-11.25^{\star \star}$ & $(-2.20)$ & $8.958^{* *}$ & $(2.38)$ \\
\hline SECURED & $6.880^{*}$ & $(1.74)$ & $-4.667^{\star}$ & $(-1.58)$ & $-9.494^{\star \star}$ & $(-2.14)$ & -4.008 & $(-0.66)$ \\
\hline CREDIT SPREAD & $5.728^{\star \star}$ & $(2.27)$ & $5.726^{\star *}$ & $(2.15)$ & $9.165^{\star}$ & $(1.97)$ & $-0.803^{\star \star *}$ & $(-2.61)$ \\
\hline Number of deals & 178 & & 165 & & 109 & & 178 & \\
\hline Adj. $R^{2}$ & 0.307 & & 0.382 & & 0.310 & & 0.280 & \\
\hline
\end{tabular}


pricing and maturities identified in the literature (Angbazo et al. (1998), Campbell and Taksler (2003)). Stapled financing reduces loan spreads for traditional bank loans, which include revolving lines of credit and for term A loans by more than 43 basis points (bps), and for term B loans by 35 bps. These effects remain economically significant even after controlling for loan- and firm-specific determinants of debt costs. Stapling also allows buyers to arrange loans of longer maturities. We next analyze this counterfactual question: What would be the estimated loan spreads for LBOs with stapled financing if they did not have such financing, and conversely? These results are presented in Table A.2 of the Internet Appendix. We find that the loan costs (maturities) for stapled deals would have been significantly higher (lower), in both statistical and economic terms, for the major loan types.

\section{Stapled Financing and Advisory Fees}

We now examine the relation of stapled financing to the payoffs that accrue to investment banks from the deal process. In M\&A, investment banks earn a variety of fees, but the "success" fee, generated in the event of the successful completion of the deal, is usually the largest payoff for banks and is negotiated by the seller and the advisor before the sale process. This fee is typically computed based on a percentage of the final transaction price (the commission rate), although the fee structure can be complex. Thus, banks offering stapled financing can potentially increase their expected fees in 2 ways: first, by negotiating higher commission rates, and second, by increasing the expected transaction price through the certification effects of stapling. We obtain information regarding these fees from proxy statements and SDC.

Table 8 analyzes the relation of investment banks' success fees to stapled financing. We use both the commission rates and the logarithm of the actual fees paid as dependent variables. We control for factors that may influence the

\section{TABLE 8}

\section{Advisory Fees and Stapled Financing}

Table 8 reports coefficient estimates from an analysis relating advisory fees paid by targets and stapled financing. The dependent variable is the percentage of fees paid by the target relative to the transaction value (\%_FEES) or natural logarithm of the dollar amount (in \$millions) of fees paid by the target, In(\$_FEES). Our sample includes all stapled leveraged buyouts (LBOs) and nonstapled LBOs. All control variables are defined in the Appendix. $t$-statistics are given in parentheses. ${ }^{\star},{ }^{\star *}$, and ${ }^{* \star *}$ indicate significance at the $10 \%, 5 \%$, and $1 \%$ levels, respectively.

\begin{tabular}{|c|c|c|c|c|}
\hline \multirow{2}{*}{$\begin{array}{l}\text { Independent } \\
\text { Variables }\end{array}$} & \multicolumn{2}{|c|}{$\begin{array}{c}\text { Dependent Variable: } \\
\% \text { \%EES }\end{array}$} & \multicolumn{2}{|c|}{$\begin{array}{c}\text { Dependent Variable: } \\
\text { In(\$_FEES) }\end{array}$} \\
\hline & Estimate & $t$-Stat. & Estimate & $t$-Stat. \\
\hline $\begin{array}{l}\text { STAPLED } \\
\text { In(TARGET_SIZE) } \\
\text { TENDER } \\
\text { HOSTILE } \\
\text { SAME_SIC } \\
\text { NUMBER_OF_ADVISORS } \\
\text { REPUTATION } \\
\text { SAME_ADV } \\
\text { PREVIOUS_RELATIONSHIPS } \\
\text { MKT }_{t-1}\end{array}$ & $\begin{array}{l}0.012^{\star} \\
0.017^{\star \star \star} \\
0.135^{\star \star} \\
-0.026^{\star} \\
-0.015^{\star \star} \\
-0.098^{\star} \\
0.156^{\star \star \star} \\
-0.016 \\
-0.035^{\star} \\
0.005^{\star}\end{array}$ & $\begin{array}{r}(1.76) \\
(3.79) \\
(2.28) \\
(1.76) \\
(-2.02) \\
(-1.98) \\
(2.80) \\
(-1.13) \\
(-1.99) \\
(1.77)\end{array}$ & $\begin{array}{l}0.007 \\
0.029^{\star \star \star} \\
0.090^{\star \star} \\
-0.057 \\
-0.062^{\star \star} \\
0.056^{\star} \\
0.219^{\star \star \star} \\
-0.048 \\
-0.030^{\star} \\
0.000\end{array}$ & $\begin{array}{r}(1.62) \\
(2.55) \\
(2.02) \\
(-1.16) \\
(-2.33) \\
(-1.72) \\
(2.90) \\
(-1.55) \\
(-1.88) \\
(1.59)\end{array}$ \\
\hline $\begin{array}{l}\text { Number of deals } \\
\text { Adj. } R^{2}\end{array}$ & $\begin{array}{r}172 \\
0.302\end{array}$ & & $\begin{array}{r}172 \\
0.277\end{array}$ & \\
\hline
\end{tabular}


negotiated commission rates. Ceteris paribus, targets in stapled deals paid $1.2 \%$ higher commission rates for success fees compared to nonstapled deals, and this difference is significant at conventional levels. In sum, our analysis confirms that investment banks offering stapled financing are able to raise their expected advisory fees by negotiating higher commission rates and by increasing the expected transaction value of the deal.

Our results thus far are consistent with the hypotheses from the certification framework in Section II. As mentioned at the outset, however, stapled financing potentially creates conflicts of interest for banks. To examine this issue, we now examine the relation of stapling to the bidding process.

\section{Stapled Financing and Bidding Competition}

Bidding in the acquisitions process is often anonymous, because the seller and the bank(s) are bound by confidentiality agreements. Both theory and evidence in auction design suggest that the anonymous, confidential nature of bidding in the prepublic phase has procompetitive features (Marshall and Marx (2009)). Boone and Mulherin (2011) find that much of the competition in corporate takeovers takes place before the revelation of a bid. Under such conditions, banks offering stapled financing may manipulate the bidding process toward buyers who will likely accept the banks' financing offers but who may not necessarily be the highest bidders. Such conflicts of interest could compromise the bidding competition.

We analyze the effects of stapling on the intensity of bidding competition and price improvement in the bidding process using 4 measures of competition employed recently in the literature (Officer et al. (2010), Boone and Mulherin (2011)): CONTACT, CONFIDENTIAL, OFFER, and POST_DUMMY. In addition to these 4 measures, we use 2 new measures: PERCENT_BID_PRICE and REVISION. These 6 measures provide an estimate of the level of competition at various stages in the takeover process. ${ }^{11}$ CONTACT is positively related to the number of potential bidders contacted by the target and the bank. CONFIDENTIAL reflects the number of bidders that express interest through a confidentiality or standstill agreement with the target. OFFER provides information about the number of potential bidders that actually submit a formal binding offer, and POST_DUMMY indicates higher interest in the target through offers made after the deal is announced. Finally, PERCENT_BID_PRICE and REVISION measure the initial offer price premium over the initial bid and the number of bid revisions, respectively, and hence are positively related to the intensity of bidding competition.

Table 9 shows that stapled financing is significantly and positively related to the excess of the final offer price relative to the initial bid price and the number of times the bid price is revised by potential acquirers. Other things held fixed, the excess of the final offer price relative to the initial bid price in stapled financing deals is $5 \%$ higher compared to nonstapled financing deals. There is a potential

\footnotetext{
${ }^{11}$ We define all six measures in the Appendix. We use DEFM14A and PREM14A filings, along with news sources, LexisNexis, Factiva, and Capital IQ to compute these measures.
} 
TABLE 9

\section{Effect of Stapled Financing on the Intensity of Bidding Competition}

Table 9 reports the regression results where the dependent variables are 6 proxies for bidding competition. Data on bidding competition are hand-collected from DEFM14A and PREM14A proxy filings and news sources. Our sample includes all stapled leveraged buyouts (LBOs) and nonstapled LBOs. All variables are defined in the Appendix. $t$-statistics are given in parentheses. ${ }^{*},{ }^{* *}$, and ${ }^{* * \star}$ indicate significance at the $10 \%, 5 \%$, and $1 \%$ levels, respectively.

\begin{tabular}{|c|c|c|c|c|c|c|c|c|c|c|c|c|}
\hline \multirow[b]{2}{*}{$\begin{array}{l}\text { Independent } \\
\text { Variables }\end{array}$} & \multicolumn{2}{|c|}{$\begin{array}{c}\text { CONTACT } \\
1\end{array}$} & \multicolumn{2}{|c|}{$\begin{array}{c}\text { CONFIDENTIAL } \\
2 \\
\end{array}$} & \multicolumn{2}{|c|}{$\begin{array}{c}\text { OFFER } \\
3 \\
\end{array}$} & \multicolumn{2}{|c|}{$\begin{array}{c}\text { POST_DUMMY } \\
4 \\
\end{array}$} & \multicolumn{2}{|c|}{$\begin{array}{c}\text { PERCENT_BID_ } \\
\text { PRICE } \\
5 \\
\end{array}$} & \multicolumn{2}{|c|}{$\begin{array}{c}\text { REVISION } \\
6 \\
\end{array}$} \\
\hline & Estimate & $t$-Stat. & Estimate & $t$-Stat. & Estimate & $t$-Stat. & Estimate & $t$-Stat. & Estimate & $t$-Stat. & Estimate & $t$-Stat. \\
\hline $\begin{array}{l}\text { STAPLED } \\
\text { ILLIQUIDITY } \\
\text { MARKET_BOOK } \\
\text { INST_OWNER } \\
\text { TAKEOVER_DEFENSE } \\
\text { STRATEGIC_BIDDER }\end{array}$ & $\begin{array}{c}2.190 \\
-0.823^{*} \\
0.606^{* * *} \\
0.748^{* *} \\
0.130^{*} \\
-0.456^{\star *}\end{array}$ & $\begin{array}{r}(1.58) \\
(-1.80) \\
(2.69) \\
(2.10) \\
(1.89) \\
(-2.39)\end{array}$ & $\begin{array}{c}1.176 \\
-0.162^{*} \\
0.277^{\star *} \\
1.008^{* *} \\
0.065 \\
-0.267^{\star}\end{array}$ & $\begin{array}{r}(1.33) \\
(-1.85) \\
(2.22) \\
(2.47) \\
(1.09) \\
(-1.88)\end{array}$ & $\begin{array}{l}1.888 \\
0.191 \\
0.115 \\
0.529^{\star \star *} \\
0.106 \\
-0.019\end{array}$ & $\begin{array}{r}(1.30) \\
(1.28) \\
(1.65) \\
(2.77) \\
(1.60) \\
(-1.19)\end{array}$ & $\begin{array}{l}0.642^{\star} \\
0.116 \\
0.122^{\star} \\
0.733^{\star \star \star} \\
0.138^{\star \star} \\
-0.005\end{array}$ & $\begin{array}{r}(1.90) \\
(1.33) \\
(1.72) \\
(2.51) \\
(2.15) \\
(-1.05)\end{array}$ & $\begin{array}{l}0.050^{\star \star} \\
0.019 \\
0.241^{\star \star} \\
0.404^{\star \star} \\
0.058 \\
-0.305^{\star \star}\end{array}$ & $\begin{array}{r}(2.30) \\
(1.47) \\
(2.10) \\
(2.18) \\
(1.49) \\
(-2.16)\end{array}$ & $\begin{array}{l}2.989^{\star *} \\
1.172 \\
0.466^{\star *} \\
0.038^{* *} \\
0.144^{*} \\
-0.188^{\star}\end{array}$ & $\begin{array}{r}(2.05) \\
(1.24) \\
(2.49) \\
(2.25) \\
(1.95) \\
(-1.74)\end{array}$ \\
\hline $\begin{array}{l}\text { Number of deals } \\
\text { Adj. } R^{2}\end{array}$ & $\begin{array}{r}186 \\
0.109\end{array}$ & & $\begin{array}{r}186 \\
0.100\end{array}$ & & $\begin{array}{r}186 \\
0.112\end{array}$ & & $\begin{array}{r}186 \\
0.115\end{array}$ & & $\begin{array}{r}186 \\
0.107\end{array}$ & & $\begin{array}{r}186 \\
0.127\end{array}$ & \\
\hline
\end{tabular}


endogeneity issue here, however, because attractive deals tend to attract greater interest from bidders. To address this concern, we reestimate the effects of stapled financing on the bidding intensity proxies using a model with latent common factors estimated by the generalized method of moments. Following Erickson and Whited (2000), we use the information contained in the third and higher order moments of the joint distribution of the observed regression variables. This approach controls for the presence of common latent determinants of bidding intensity and stapled financing, and it is robust to nonsymmetric distributions (see Aslan and Kumar (2012)). The results, which are untabulated, reinforce those given in Table 9.

The analysis here complements the finding that banks earn higher commission rates from stapled targets. As Mehran and Stulz (2007) point out, market participants consider financial intermediaries' conflicts of interest when making their decisions. Sellers are presumably unlikely to pay higher advisory fees in stapled deals if they expect the stapled offer to affect adversely the expected sale price.

\section{Robustness Tests}

To conduct our robustness tests, we first follow the recent literature (Bargeron et al. (2008)) and measure market capitalization of firms 63 days before the bid announcement. Our results are robust to measuring the equity values 5 days before the announcement. We also include the seven strategic bidders in our analysis, although their bidding motivations may differ from those of the financial bidders. Hence, we recalculate the target CARs for stapled and nonstapled deals by excluding these seven strategic bidders. The results are materially unaffected. We also analyze the CARs for the largest $50 \%$ of public (non-LBO) deals. In univariate analysis, we find that stapled deals have significantly higher CAR-VW relative to public deals in the postannouncement and short windows, but there is no significant difference between the CAR-VW of nonstapled and public deals. Similarly, the positive effects of stapling on the CAR-VW in the multivariate analysis (Table 4) are robust. In addition, we use targets' stock return volatility, measured as the standard deviation of returns over the previous 12 months, as a measure of asymmetric information; the results are similar. Finally, to address the possibility that significance levels may be overstated because of repeat buyers, we cluster standard errors by buyer and obtain similar significance levels for the key coefficient estimates.

\section{Conclusion}

Financial intermediaries play an important information production role in the acquisitions process. Stapled financing, where the seller prearranges a financing commitment from its financial advisors, can provide value certification of target firms but also raises potential conflicts of interest if banks use it mainly to generate lending business for themselves. These issues exemplify the tension that arises when financial intermediaries perform both an information production and a financing function. Using a unique data set, and controlling for 
endogeneity effects, we find that stapled financing has significant certification effects, moderating the adverse selection discount on sale prices and lowering the debt financing costs of acquisitions. The analysis supports the predictions of a signaling framework where informed intermediaries in M\&A certify the economic and financial strength of targets by providing ex ante financing commitments.

Our study suggests that stapled financing played a major role during the LBO boom of 2004-2007 because it is especially effective in certifying higher debt capacity that facilitates deal financing through debt. Nevertheless, stapled financing has not been used as intensively recently, especially after 2011. This relatively low use of stapled financing is consistent with the received theory of efficient signaling (Milgrom and Roberts (1986)). When certification can occur through multiple signals, as is the case in M\&A, signals are chosen to economize on dissipative costs. Thus, the relative decline in LBO activity (compared to its boom years in the previous decade) along with increased credit and private equity financing for M\&A help explain the lower recent use of stapled financing.

\section{Appendix. Variable Definitions}

This Appendix contains variable names, definitions, and Compustat mnemonics.

AMIVEST_ILLIQUIDITY_RATIO: Average ratio of firm $i$ 's reported daily dollar volume to its absolute stock return over all days in a year with nonzero return (from CRSP).

AVERAGE_NUMBER_OF_BIDDERS: Mean number of bidders (defined below) per deal.

CASH: Binary measure equal to 1 for acquisitions in which the payment is all cash, and 0 otherwise (from company filings and SDC).

CLUB_BIDDING: Dummy variable that equals 1 for club deal targets, and 0 otherwise (from news articles and company filings).

CONFIDENTIAL: Natural log of the number of potential bidders engaged in a confidentiality or standstill agreement with the target (from company filings).

CONTACT: Natural log of the number of potential bidders with which the target and its investment bank were in contact (from company filings).

CREDIT_SPREAD: Difference between the yields of BB- versus AAA-rated corporate bonds.

DISC_ACCRUALS: Discretionary accruals from Dechow and Dichev (2002), where the working capital accruals $-(\mathrm{RECCH}+\mathrm{INVCH}+\mathrm{APALCH}+\mathrm{TXACH}+$ $\mathrm{AOLOCH}$ ) are regressed on the past, present, and future cash flows from operations (OANCF), and the standard deviation of residuals is a proxy for discretionary accruals.

ILLIQUIDITY: Measure of stock illiquidity from Amihud (2002), calculated as the daily ratio of absolute stock return to dollar volume 63 days before the bid announcement (from CRSP).

INST_OWNER: Percentage of institutional stock ownership in target firm (from Form 13F).

INTANGIBLES: Ratio of intangibles (INTAN) to total assets (AT).

LENDING_RELATIONSHIPS: Binary measure of relationship designed to pick up the existence of prior lending by the same lender to the target firm in the past 5 years (from DealScan). 
LEVERAGE: Ratio of the book value of total debt (short term (DLC) and long term (DLTT)) to the book value of assets (AT).

$\ln$ (RELATIVE_SIZE): Natural log of the equity value of the target divided by the bidder size 63 days before the bid announcement (from CRSP).

$\ln$ (TARGET_SIZE): Natural log of the market value of the target calculated 63 days before the bid announcement (from CRSP).

LOAN_SPREAD: All-in-drawn spread above benchmark (from DealScan and company filings).

MARKET_BOOK: Ratio of market value of equity 63 days before the bid announcement (from CRSP) to book value of equity (CEQ) in the year before the merger.

MATURITY: Length in months between loan facility activation date and maturity date (from DealScan and company filings).

$\mathrm{MKT}_{t-1}$ : Lagged daily return on the value-weighted CRSP index return.

NUMBER_OF_ADVISORS: Natural log of the number of merger advisors for the target firm (from SDC and Capital IQ).

NUMBER_OF_BIDDERS: Natural log of the number of potential bidders agreeing to sign the confidentiality and/or standstill agreements (from company filings).

OFFER: Natural log of the number of potential bidders that submitted formal binding offers for the deal (from company filings).

OPACITY: Index of adverse selection based on measures of adverse selection developed by the market microstructure literature, details of which are provided in the text (from CRSP).

PAST_STOCK_RETURN: Return to the target's stock compounded over 12 months immediately preceding trading day -42 relative to the announcement date minus the compounded return to the CRSP value-weighted market index over the same period.

PERCENT_BID_PRICE: Excess of the initial offer price relative to the initial bid price (in percentages) (from company filings).

POST_DUMMY: Binary variable equal to 1 when another potential acquirer bids for the target 6 months after the deal announcement is made, and 0 otherwise.

PREVIOUS_RELATIONSHIPS: Binary variable equal to 1 if there is a prior advisory and lending relationship between each seller and sell-side advisor before the current deal, and 0 otherwise (from SDC and Dealscan).

PROFITABILITY: Earnings before interest and taxes (OIADP + NOPI), divided by the book value of assets (AT).

REPUTATION: Market share rank of a sell-side advisor in any given year. Market share is calculated as the ratio of the total dollar value of all mergers completed by the sellside advisor in that year to the total dollar value of all mergers in the same year (from SDC).

REVISION: Natural log of the number of times the bid price is revised by potential acquirers (from company filings).

SAME_ADV: Binary variable equal to 1 if at least one of the merger advisors is advising both the target and the acquiring firms for the given deal, and 0 otherwise.

SAME_SIC: Dummy variable equal to 1 if both the target and the acquiring firms are in the same industry, and 0 otherwise.

SECURED: Binary variable equal to 1 for secured loans, and 0 otherwise (from DealScan and company filings).

STAPLED: Binary variable equal to 1 for stapled LBO deals, and 0 for nonstapled LBO deals (from news articles and company filings). 
STRATEGIC_BIDDER: Binary variable equal to 1 when there are strategic buyers in the pool, and 0 otherwise (from company filings).

SYNDICATE: Natural log of the number of lenders in a loan syndicate (from DealScan and company filings).

TAKEOVER_DEFENSE: Number between 0 and 1, with a higher number indicating stronger takeover defenses. It is determined by assigning values to various aspects of takeover defenses the target has implemented and averaging these weighted points (from Capital IQ).

TENDER (HOSTILE): Binary variable equal to 1 if the takeover offer is a tender (hostile) offer, and 0 otherwise (from SDC).

TEV: Total enterprise value (from Capital IQ), which is calculated as the market capitalization at the delisting date (from CRSP) + total debt (DLC + DLTT) - cash (CHE).

TURNOVER: Stock trading volume (from CRSP) divided by market value of the target 63 days before the announcement of bids.

VOLATILITY: Standard deviation of the ratio of operating income before depreciation (OIBDP) to book value of assets (AT) over the trailing 12 quarters.

\section{References}

Allen, F. "The Market for Information and the Origin of Financial Intermediation.” Journal of Financial Intermediation, 1 (1990), 3-30.

Allen, L., and S. Peristiani. "Loan Underpricing and the Provision of Merger Advisory Services." Journal of Banking and Finance, 31 (2007), 3539-3562.

Amihud, Y. "Illiquidity and Stock Returns: Cross Section and Time-Series Effects." Journal of Financial Markets, 5 (2002), 31-56.

Amihud, Y.; H. Mendelson; and B. Lauterbach. "Market Microstructure and Securities Value: Evidence from the Tel Aviv Exchange." Journal of Financial Economics, 45 (1997), 365-390.

Angbazo, L.; J. Mei; and A. Saunders. "Credit Spreads in the Market for Highly Leveraged Transaction Loans.” Journal of Banking and Finance, 22 (1998), 1249-1282.

Aslan, H., and P. Kumar. "Strategic Ownership Structure and the Cost of Debt." Review of Financial Studies, 25 (2012), 2257-2299.

Bargeron, L.; F. Schlingemann; R. Stulz; and C. Zutter. "Why Do Private Acquirers Pay So Little Compared to Public Acquirers?" Journal of Financial Economics, 89 (2008), 375-390.

Barth, M.; R. Kasznik; and M. McNichols. "Analyst Coverage and Intangible Assets." Journal of Accounting Research, 39 (2001), 1-34.

Beatty, R., and J. Ritter. "Investment Banking, Reputation and Underpricing of Initial Public Offerings.” Journal of Financial Economics, 15 (1986), 213-232.

Bharath, S.; P. Pasquariello; and G. Wu. "Does Asymmetric Information Drive Capital Structure Decisions?" Review of Financial Studies, 22 (2009), 3211-3243.

Bhattacharya, S. "Imperfect Information, Dividend Policy, and 'The Bird in the Hand' Fallacy." Bell Journal of Economics, 10 (1979), 259-270.

Boone, A. L., and J. Mulherin. "Do Private Equity Consortiums Impede Takeover Competition?" Working Paper, Kansas State University and University of Georgia (2008).

Boone, A. L., and J. Mulherin. "Do Private Equity Consortiums Facilitate Collusion in Takeover Bidding?" Journal of Corporate Finance, 17 (2011), 1475-1495.

Campbell, J., and G. Taksler. "Equity Volatility and Corporate Bond Yields." Journal of Finance, 58 (2003), 2321-2349.

Capron, L., and N. Pistre. "When Do Acquirers Earn Abnormal Returns?" Strategic Management Journal, 23 (2002), 781-794.

Carter, R., and S. Manaster. "Initial Public Offerings and Underwriter Reputation.” Journal of Finance, 45 (1990), 1045-1067.

Chon, G., and A. Das. "A Ruling to Chill Wall Street.” Wall Street Journal (Feb. 18, 2011), C1.

Coase, R. "The Nature of the Firms." Economica, 4 (1937), 386-405.

Dechow, P., and I. Dichev. "The Quality of Accruals and Earnings: The Role of Accrual Estimation Errors.” Accounting Review, 77 (2002), 35-59.

Diamond, D. "Financial Intermediation and Delegated Monitoring." Review of Economic Studies, 51 (1984), 393-414. 
Diamond, D., and R. Verrecchia. "Disclosure, Liquidity, and the Cost of Capital." Journal of Finance, 46 (1991), 1325-1359.

Erickson, T., and T. Whited. "Measurement Error and the Relationship between Investment and $q$." Journal of Political Economy, 108 (2000), 1027-1057.

French, K., and R. McCormick. "Sealed Bids, Sunk Costs, and the Process of Competition." Journal of Business, 57 (1984), 417-441.

Guo, S.; E. Hotchkiss; and W. Song. "Do Buyouts (Still) Create Value?” Journal of Finance, 66 (2011), 479-517.

Heckman, J. "Sample Selection Bias as a Specification Error.” Econometrica, 47 (1979), 153-161.

Jensen, M., and W. Meckling. "Theory of the Firm: Managerial Behavior, Agency Costs and Ownership Structure.” Journal of Financial Economics, 3 (1976), 305-360.

Jensen, M., and R. Ruback. "The Market for Corporate Control." Journal of Financial Economics, 11 (1983), 5-50.

Kale, J. R.; O. Kini; and H. Ryan. "Financial Advisors and Shareholder Wealth Gains in Corporate Takeovers." Journal of Financial and Quantitative Analysis, 38 (2003), 475-501.

Kaplan, S., and J. Stein. "The Evolution of Buyout Pricing and Financial Structure in the 1980s." Quarterly Journal of Economics, 108 (1993), 313-357.

Karpoff, J. "The Relation between Price Changes and Trading Volume: A Survey." Journal of Financial and Quantitative Analysis, 22 (1987), 109-126.

Leland, H., and D. Pyle. "Informational Asymmetries, Financial Structure and Financial Intermediation.” Journal of Finance, 32 (1977), 371-387.

Logue, D. "On the Pricing of Unseasoned Equity Issues: 1965-1969." Journal of Financial and Quantitative Analysis, 8 (1973), 91-103.

Maddala, G. S. Limited-Dependent and Qualitative Variables in Econometrics. Cambridge, UK: Cambridge University Press (1983).

Marshall, R. C., and L. Marx. "The Vulnerability of Auctions to Bidder Collusion." Quarterly Journal of Economics, 124 (2009), 883-910.

Mehran, H., and S. Peristiani. "Financial Visibility and the Decision to Go Private." Review of Financial Studies, 23 (2009), 519-547.

Mehran, H., and R. Stulz. "The Economics of Conflicts of Interest in Financial Institutions." Journal of Financial Economics, 85 (2007), 267-296.

Milgrom, P., and J. Roberts. "Price and Advertising Signals of Product Quality." Journal of Financial Economics, 94 (1986), 796-821.

Myers, S. "The Determinants of Corporate Borrowing." Journal of Financial Economics, 5 (1977), $147-175$.

Pastor, L., and R. Stambaugh. "Liquidity Risk and Expected Stock Returns." Journal of Political Economy, 111 (2003), 642-685.

Officer, M.; O. Ozbas; and B. Sensoy. "Club Deals in Leveraged Buyouts." Journal of Financial Economics, 98 (2010), 214-240.

Povel, P., and R. Singh. “Stapled Finance.” Journal of Finance, 65 (2010), 927-953.

Puri, M. "Commercial Banks in Investment Banking: Conflict of Interest or Certification Role?" Journal of Financial Economics, 40 (1996), 373-401.

Riley, J. “Informational Equilibrium.” Econometrica, 47 (1979), 331-359.

Spence, A. M. "Job Market Signalling." Quarterly Journal of Economics, 90 (1973), 225-243.

Thomas, S. "Firm Diversification and Asymmetric Information: Evidence from Analysts Forecasts and Earnings Announcements." Journal of Financial Economics, 64 (2002), 373-396.

Vermaelen, T. "Common Stock Repurchases and Market Signalling.” Journal of Financial Economics, 9 (1981), 139-183.

Williamson, O. Markets and Hierarchies: Analysis and Antitrust Implications. New York, NY: Free Press (1975). 